\title{
Genomics and identity: the bioinformatisation of human life
}

\author{
Hub Zwart
}

Published online: 26 February 2009

(C) The Author(s) 2009. This article is published with open access at Springerlink.com

\begin{abstract}
The genomics "revolution" is spreading. Originating in the molecular life sciences, it initially affected a number of biomedical research fields such as cancer genomics and clinical genetics. Now, however, a new "wave" of genomic bioinformation is transforming a widening array of disciplines, including those that address the social, historical and cultural dimensions of human life. Increasingly, bioinformation is affecting "human sciences" such as psychiatry, psychology, brain research, behavioural research ("behavioural genomics"), but also anthropology and archaeology ("bioarchaeology"). Thus, bioinformatics is having an impact on how we define and understand ourselves, how identities are formed and constituted, and, finally, on how we (on the basis of these redefined identities) assess and address some of the more concrete societal issues involved in genomics governance in various settings. This article explores how genomics and bioinformation, by influencing research agendas in the human sciences and the humanities, are affecting our self-image, our identity, the way we see ourselves. The impact of bioinformation on self-understanding will be assessed on three levels: (1) the collective level (the impact of comparative genomics on our understanding of human beings as a species), (2) the individual level (the impact of behavioural genomics on our understanding of ourselves as individuals), and (3) the genealogical level (the impact of population genomics on our understanding of human history, notably early human
\end{abstract}

H. Zwart ( ()

Faculty of Science, Department of Philosophy \& Science Studies, Centre for Society \& Genomics, Radboud University Nijmegen, P.O. Box 9010, 6500 GL Nijmegen, The Netherlands e-mail: h.zwart@science.ru.nl history). This threefold impact will be assessed from two seemingly incompatible philosophical perspectives, namely a "humanistic" perspective (represented in this article by Francis Fukuyama) and a "post-humanistic" one (represented by Peter Sloterdijk). On the basis of this analysis it will be concluded that, rather than focussing on human "enhancement" by adding or deleting genes, genome-oriented practices of the Self will focus on using genomics information in the context of identity-formation. Genomic bioinformation will increasingly be built into our self-images and used in order to tailor and adapt our practices of Self to our "personalised" genome. We will keep working on ourselves, no doubt, not by modifying our genomes, but rather by fine-tuning our behaviour. What we are experiencing is a bioinformatisation of the life-world. Genomics-based technologies will increasingly pervade our daily lives, our autobiographies and narratives, as well as our anthropologies, rather than our genomes as such.

Keywords Genomics · Identity · Bioinformation · Anthropotechnologies · Post-humanism .

Francis Fukuyama · Peter Sloterdijk

\section{Introduction: genomics and bioinformatics as emerging fields}

The Human Genome Project (1990-2004) symbolises the emergence of genomics as a new techno-scientific field (IHGSC 2001, 2004), building on technologies for high throughput bioinformatics and opting for a whole genomeoriented, rather than for a single gene-oriented approach. It has resulted in a steady stream of ever-larger and more complex genomic data sets, thus transforming the study of virtually all forms of life. Genomics is not a particular 
branch of biology, but rather a transformation of the ways in which research in the life sciences is done (Collins et al. 2003). In various research fields, it has provided researchers with new research strategies that allow or challenge them to reframe and redefine their basic issues.

Bioinformatics can be regarded as the "core" discipline of genomics. It develops statistical and computational techniques to analyse large amounts of biological information in a data-driven-rather than hypothesis-drivenfashion. According to the NIH working definition, ${ }^{1}$ bioinformatics can be defined as research, development and application of computational tools for the use of biological, medical, behavioural or health data (the acquisition, storage and visualisation of such data). The emergence of bioinformatics is not a purely academic affair. On the contrary, it is part of the social reality of today. The bioinformatisation of science reflects and supports the "bioinformatisation" of life and of society at large. New forms of bioinformation allow new identities, new categorisations and new forms of social organisation to emerge. Large-scale population databases open up new forms of societal monitoring and surveillance, while individuals and consumers are invited to use personalised bioinformation in order to tailor their life style and diets to their genomes.

Bioinformatics analyses "in silico DNA", thereby facilitating the "informatisation" of life. Large amounts of bioinformation are becoming available in electronic formats for research communities worldwide. Because bioinformation is immaterial, it can be more easily managed, analysed and manipulated than the material realities it represents (Gaskell and Bauer 2006, p. 10). An exemplification of the key role of bioinformatics in genomics is GenBank, the NIH genetic sequence database, an annotated collection of all publicly available DNA sequences. The emergence of bioinformatics has not only affected the ways in which knowledge is produced and disseminated, but also resulted in an increase of the scale and pace of life science research, as large consortia are sequencing and analysing the genomes of a steadily growing number of species.

As Thacker (2005) and others have argued, genomics has resulted in DNA now being available in more than one format: besides "wet" or living DNA (DNA in organisms, cells or test tubes) we have access to "dry" DNA, stored in computer databases, lap tops or on CS-ROMs, to be downloaded and disseminated electronically through portals and electronic networks. This mobility of biological information across media (living bodies, laboratories, Internet sites, databases, patent offices), its availability in vivo, in vitro as well as in silico, enhances its usability. Thus, bioinformatics is more than a mere "tool". It is

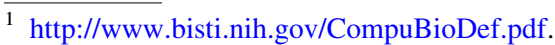

transforming agendas for research and reshaping agendas for societal debate.

The genomics "epidemic" is spreading. Originating in the molecular life sciences, it initially affected a number of biomedical research fields, such as cancer genomics and clinical genetics. Now, however, a new "wave" of bioinformation is transforming a widening array of disciplines, including those that address the social, historical and cultural dimensions of human life. Increasingly, bioinformation is affecting "human sciences" such as psychiatry, psychology, brain research, behavioural research ("behavioural genomics"), but also anthropology and archaeology ("bioarchaeology"). Thus, bioinformatics is having an impact on how we define and understand ourselves, how identities are formed and constituted, and, finally, on how we (on the basis of these emerging identities) assess and address some of the more concrete societal issues involved in genomics governance in various settings.

This article explores how genomics and bioinformation, by influencing research agendas in the human sciences and the humanities, are affecting our self-image, our identity, the way we see ourselves. The impact of bioinformation on self-understanding will be assessed on three levels:

(1) the collective level: the impact of comparative genomics on our understanding of human beings as a species (species identity);

(2) the individual level: the impact of behavioural genomics on our understanding of ourselves as individuals (personal identity), and

(3) the genealogical level: the impact of population genomics on our understanding of human history (historical identity).

On all three levels, the traditional "humanistic" view concerning the humanness of human beings is under pressure. Indeed, the genomics revolution has fuelled a debate between a humanistic and a post-humanistic understanding of what it means to be human. In this article, Francis Fukuyama and Peter Sloterdijk will be regarded as "spokespersons", as it were, of a humanistic and posthumanistic understanding respectively. Building on their writings, the question will be addressed how the bioinformation of our self-understanding revivifies some of the basic questions of philosophical anthropology. And this is more than merely an "academic" exercise, as our basic view of ourselves, our philosophical anthropology, will affect the way we assess the uses of genomics-based applications now and in the future. This notably applies to genomics-based technologies that, at some point in the future, may assist us in enhancing and developing ourselves, either individually or collectively. 
The impact of bioinformation on our collective identity: who are we?

"God bless me, the man seems hardly human! Something troglodytic, shall we say" (Robert Louis Stevenson, Dr. Jekyll and Mr. Hyde $)^{2}$

In a famous essay Freud (1917/1947) has argued that major scientific discoveries entail narcissistic "offences". Whereas we tend to see ourselves as central and unique, scientific research time and again exposes us to the fact that we are not, at least not in the way we initially imagined. Copernican heliocentrism for example demonstrated that we, rather than occupying a stable and central position in the universe, are aimlessly floating through the cold, dark, silent and infinite immensities of space. Subsequently, Darwin's theory of evolution indicated that we do not fundamentally differ from other species. We are not a special kind of entity, but merely one species among others, the outcome of a process of evolution that will continue to shape and change us. As a third major offence, Freud listed-somewhat narcissistically perhaps-psychoanalysis: the message that we are not master in our own house, but rather driven by unconscious impulse.

The Human Genome Project (HGP) can be regarded as the most recent in a whole series of narcissistic offences (Zwart 2007a), first of all because of the surprisingly small number of genes on the human genome (in comparison to other, apparently less complex "model" species such as worms, flies and plants), but also because of the surprisingly small differences between the human genome and the genomes of other mammals such as the chimpanzee or the laboratory mouse. Whereas initial estimates concerning the number of protein-coding genes on the human genome ranged from $\sim 100,000$ up to $\sim 200,000$, it was eventually concluded that the human genome contains something like $\sim 22,500$ genes, which was something of a surprise. ${ }^{3}$ Moreover, comparative genomics has shown that seemingly very different organisms are-genomically speaking at least- "amazingly like humans" (Nature 437, 7055, p. 47) and that notably the differences between the common chimpanzee (Pan troglodytes) and Homo sapiens appear to be very minute indeed.

On September 1, 2005 The Chimpanzee Sequencing and Analysis Consortium published the draft genome sequence of the common chimpanzee in Nature. It was presented as a final confirmation of the Darwinian claim that humans and primates share recent common ancestors (they separated

\footnotetext{
${ }^{2}$ Stevenson (1886/1981, p. 18).

3 Notably when compared to the number of genes on other model genomes such as those of Drosophila melanogaster ( $\sim 14.000$ genes), Caenorhabditis elegans ( $\sim 19.000$ genes) and Arabidopsis thaliana ( $\sim 25.000$ genes).
}

about 5 million years ago). The work of Wolfgang Köhler (describing how chimpanzees solve problems), Jane Goodall (describing how chimpanzees use tools) and Frans de Waal (describing how chimpanzees engage in group politics) already revealed a number of "startling behavioural similarities" (p. 69), but now genomics research indicates, according to the authors, that chimpanzees "are especially suited to teach us about ourselves" (p. 69), both in terms of their similarities and in terms of their differences with humans. Indeed, the availability of "a second hominid genome" (p. 83) revivifies the question: "what makes us human?" (p. 83). ${ }^{4}$

It may seem somewhat premature to so eagerly include the HGP in this impressive series of major scientific breakthroughs or Copernican revolutions. Perhaps we should rather be more reluctant when it comes to determining whether the impact of the HGP will really equal the grand expectations of those immediately involved. On the other hand, none of these listings is beyond contestation. Copernicus' publication on the "revolutions" of the heavenly bodies more or less went unnoticed in 1543 and in many respects Copernicus still adhered to traditional ideas, such as the one articulated in the very first sentence of Book I, namely that the universe must be spherical as "the sphere is the most perfect of all forms" (1978/1992, p. 8). Moreover, although psychoanalysis must have seemed a major revolution in the eyes of Freud and his followers, the question whether Freud's impact really equalled that of, say, Darwin is a difficult one to answer. Nonetheless, I belief that the halo of significance associated with the HGP reflects more than mere science rhetoric. Comparative genomics inevitably challenges us to redefine ourselves. For centuries "we"and this notably refers to "philosophers"-have been framing the relationship between humans and other animals, including primates, in terms of discontinuity. We experienced ourselves as fundamentally different, as an "animal rationale", a species or entity that "had" something which other species lacked (be it a "soul" or the capacity to "reason" and "reflect"). Other species were defined in terms of a basic ontological deficiency. Indeed, we tended to regard ourselves, not as a species, but as a distinct ontological category, and for good reasons, so it seemed, as the discontinuity between us and other animals (including primates) seems undeniable. We live in a highly advanced techno-cultural environment of our own making. Although (other) primates may communicate with one another, their communication techniques do not equal the symbolic

\footnotetext{
4 "We still do not have in our hands the answer to the most fundamental question: what makes us human? But this genomic comparison dramatically narrows the search for the key biological differences between the two species". Robert Waterston, cited in "BBC News, 'Life code' of chimps laid bare". http://newsvote.bbc. co.uk, Monday 5 April 2004.
} 
complexities of human language use. And although (other) primates may engage in forms of group dynamics that to a certain extent can be described as "politics", these behavioural patterns can never equal the complex symbolical order of representative democracies, or the intricate governmental systems devoted to managing the peaceful coexistence and collaboration of large numbers of people through longdistance governance and advanced techniques of administration. Still, these apparently undeniable differences are not immediately visible if we merely look at our genomes. From the point of view of comparative genomics, the humanity of human beings seems to evaporate.

Whereas the HGP focussed on the genome of mankind as such, the next step will be to take up sequencing the genomes of individuals. This process has already started. The individual genome sequences of genomics pioneers such as Craig Venter and James Watson are electronically available and the number of individuals who actually have access to their personal genomic sequence is rapidly (if not exponentially) increasing. What does this mean for how we see ourselves? How is genomics affecting our self-understanding on the individual level?

\section{The impact of bioinformation on our personal identity: the personalised genome}

It is generally expected that, within 10 years or so, the famous $\$ 1,000$ (or $€ 1,000$ ) personal genome sequence will be affordable and available for citizens. In his recent autobiography A life decoded, Venter (2007) not only relates, from an insider's perspective, how bioinformation changed the biomedical research landscape, but he also demonstrates what the impact of personalised genomics might be in the near future. Venter was one of the first individuals who had the privilege of seeing and studying his own personal genome sequence. Thus, his autobiography not only tells us the story of his life (parents, youth in California, traumatic experiences in Vietnam, fierce opposition from envious competitive colleagues, etc.), as autobiographies by scientists usually do. In at least one respect, his autobiography is unprecedented and unique. Repeatedly, the narrative is interrupted by text-boxes informing us about a particular gene Venter encountered on his personal genome. Notably, he focuses on genes that are associated with behavioural characteristics, such as ADHD, risk-seeking behaviour and stress tolerance. In retrospect he explicitly makes a series of connections between the vicissitudes of his life and the genes on his genome. In doing so, he may well be setting a standard for how in the near future personalized genomics information may be applied in the context of self-understanding and self-assessment. Venter's autobiography may constitute a paradigm for future practices of the Self. In the future, individuals may redirect their ambitions and training trajectories, for instance, on the basis of their genome. It is certainly no coincidence that Venter's autobiography coincides in time with the emergence of behavioural genomics.

Venter's autobiography also coincides in time with Michael Crichton's most recent novel Next (2006), another example of a document that explores the impact of personalised bioinformation on individual self-understanding. The book can be read as a literary scenario study devoted to outlining the meaning of genomics for identity-formation. It introduces a number of individuals who are actively engaged in redefining themselves in terms of their genetic profile. The various story lines develop around a number of "genes for"-genes that supposedly co-determine behavioural characteristics, such as the maturity gene, the novelty-(or thrill-seeking) gene, the sociability gene and the infidelity gene. The maturity gene, for instance, puts deviant forms of behaviour, such as drug addiction, in a new, genome-based perspective, one that has far-reaching implications for how individuals see their responsibility in shaping their own lives as well as for how they relate to parents, brothers, sisters and spouses. Genomics technologies are used for a broad variety of "practices of the Self", to use a Foucauldian term, and Crichton outlines their possible impact on identity-development, ranging from paternity testing and partner selection to the ways in which individuals present themselves in court. For instance, while some lawyers recommend screening for the novelty-seeking gene as a possible mitigating circumstance on behalf of clients who happen to engage in risky lifestyles, others suggest to subject former partners to genetic screening in the context of custody cases. Like Venter's autobiography, Crichton's book reflects, albeit in a somewhat exaggerated and soap-like fashion, the societal implications of current developments in behavioural genomics. And although some of the events described seem to take the logic of behavioural genomics to the point of absurdity, in most cases there are traceable connections with ongoing research programs (Zwart 2007b).

As Asherson (2005) and other behavioural genomics experts have argued, the sequencing of the human genome has opened up ways for investigators in behavioural studies to identify genes that may influence human behaviour. It is clear, of course, that this will be a complex task since human behaviour as a rule does not result from simple oneto-one relationships with causal genes. Rather, what will be discovered are complex networks of co-acting, correlated and interactional factors. Yet, despite the inherent complexity that is to be expected, "combining quantitative and molecular genetic strategies with social, developmental, environmental, neurobiological and psychological methods holds the promise of elucidating major components of 'aetiological networks"' involved in behavioural traits such 
as Attention-Deficit/Hyperactivity Disorder or susceptibility to drug abuse (p. 1). In the near future, genomic bioinformation may gradually replace, or at least complement, information from other sources such as psychological tests, psychotherapy and family history — or even astrology.

Thus, personalised genomics may well generate a whole range of issues and questions that have to do with how identities are defined and how new categories in terms of personality traits, psychic typologies, accountability etc. are bound to emerge. Will this development "empower" citizens to "manage" their own lives, to shape their own biographies and futures; will they be enabled to "relate" critically and creatively to their genomic "profiles", as authors of their own life stories? Or will it rather lead to practices of exclusion and surveillance, that is: will individuals rather be defined by new genomics-based practices of categorisation? Those are the type of normative questions that are likely to result from these developments. Instead of presenting ourselves as "choleric" or "melancholic", or as "introvert" rather than "extravert", we may in the future develop new typologies that will increasingly rely on the idioms of genomics.

Besides the collective genome of mankind and the genomes of individuals, the unravelling of human genomics unfolds in yet another direction, namely along the lines of history. When it comes to understanding ourselves, history is important. Human beings tend to see themselves as the outcome of a dramatic historical narrative, characterized by a number of decisive turning points. Also in this dimension, genomics is redefining the field.

\section{The impact of bioinformation on our genealogical identity: the domesticated genome}

Genomics and bioinformatics are not only affecting biomedical or behavioural sciences such as psychiatry and psychology, but also research fields that are usually regarded as belonging to the humanities side of the spectrum, such as archaeology. Luca Cavalli-Sforza and Allan Wilson's Human Genome Diversity Project (also known as the "second" Human Genome Project) as well as the HapMap project and the Genographic Project ${ }^{5}$ of National Geographic and IBM are shedding new light on (early) human history and have re-opened a number of debates in archaeology, palaeontology, language studies and cultural anthropology that are of key importance for our understanding of the origins of human society and culture (Cavalli-Sforza and Cavalli-Sforza 1995; Stone and Lurquin 2005). By affecting our views on our own pre-historical origins, these research programmes may well influence the

\footnotetext{
5 https://www3.nationalgeographic.com/genographic/.
}

ways in which we see our place in the contemporary world. The impact of genomics on human sciences and humanities has a clear "societal relevance", as our views of ourselves as social and cultural beings, as well as our understanding of our origin and past, will profoundly affect the ways in which we define and position ourselves in current debates on the use of various genomics applications, now and in the future. The projects mentioned are part of an emerging landscape in which identities are made and unmade (M'charec 2005; Nash 2005). It affects views on identity and history both in the academic as in the public realm.

In the academic realm, genomics is having a tremendous impact on research agendas. Its impact on archaeology is exemplified by a recent science autobiography, written by the prominent archaeologist Jones (2001). His book is actually an analysis in retrospect of the bioinformatisation of his field. Jones describes how bioinformation has transformed archaeology in a very profound way-has transformed it into bioarchaeology. The focus of attention has shifted from analysing artefacts such as pottery or ornaments or tools, to analysing DNA fragments in organic remains (seeds, animal bones, human bones, etc.) as sources of information concerning the health and nutrition of ancient rural communities. The focus of interest of bioarchaeology is on the plants these rural communities cultivated, on the animals they domesticated, on the "biotechnologies" they used (notably micro-organisms such as yeast for purposes of fermentation) as well as on the man-made ecosystems they created. Due to this shift, archaeologists became "molecule hunters". Contemporary archaeologists are overwhelmed by huge amounts of bioinformation. Their research practice reflects what Thacker (2005) has termed the "excess" of bioinformation. And Jones also emphasises what was already argued above, namely that our (changing) view on early human history has a "relevance" for society today: it affects the way we see ourselves and our place in nature (p. 40).

Of special importance in this respect is the so-called Neolithic revolution: the emergence of agriculture $\sim 10,000$ years ago in the Near East, China, India and Mexico. In the context of this historical marker of pivotal importance, mankind began to create artificial environments: controlled, domesticated landscapes. Instead of consuming food products that were provided by natural habitats, human beings began to produce their own food. This dramatically changed the human way of life. Mankind began to settle down. A human life-world emerged. We domesticated plants, animals and environments-but we primarily domesticated ourselves. This process is documented in human DNA, either "old" DNA (encountered in bones and other remains) or "modern" DNA (the DNA of living individuals as a kind of archive containing information on, for instance, early human migration routes). But 
bioarchaeology is also interested in the genomes of other species, especially plants species such as cereals and rice, but also animal species such as dogs, horses, camels, cows and pigs, organisms that became part of the new agricultural, anthropogenic ecosystems, of the Neolithic Arks that provided shelter, a protective shell or sphere that safeguarded not only ourselves but our domesticated partner species as well from direct exposure to natural environments. Thus, genomics may allow us to reconstruct, more accurately than ever before, the history and genesis of what in phenomenology is termed the human life-world. In recent years, not only the human genome has been sequenced, but the genomes of a number of other "domesticated" species as well, plants and animals whose destinies became intimately connected with ours. ${ }^{6}$ One of the consequences is that our view of early human history is shifting from an anthropocentric view towards a much more ecocentric perspective: the early development of rural communities as multi-species networks. In ancient rural environments, humans, cultivated plants and domesticated animals became involved in complex processes of co-evolution, mutually beneficial to the various species involved.

This already started long ago, even before the onset of the Neolithic revolution, as ancient hunters and gatherers managed to survive, not only because of their unique cognitive qualities as human beings, but also because of the complementary skills and talents of their dogs. As sledge dogs or pack animals, these domesticated animals significantly increased human mobility, and as hunters they proved outstanding team players. Dogs and humans have to some extent domesticated each other, "forging a hunting partnership that was advantageous to both" (p. 111).

Subsequently, in the context of the Neolithic revolution, animals became involved in the process of domestication, an important turning point in human history. While the ancestors of domesticated cows, horses and camels became extinct, domestication provided a "life line" for these species. At the same time, they contributed to human survival under difficult or even adverse conditions. The history of these inter-species communities and their intercontinental journeys can now be reconstructed in more reliable ways, either by means of "old" DNA (analysis of remains of humans as well as of cultivated plants and domesticated species) or by means of "modern" DNA (in vivo genomes, used as archives containing markers and footprints reflecting past events such as migratory journeys).

This academic rewriting of collective genealogical trajectories coincides with a growing impact of genomics-

\footnotetext{
${ }^{6}$ Examples of genomics "milestones" in this respect are research concerning the genomic evolution of species such as rice (Normile and Pennisi 2002), pig (Larson et al. 2007) and cow: http://www. hgsc.bcm.tmc.edu/projects/bovine/, http://www.sciencedaily.com/ releases/2006/08/060819112235.htm.
}

based tools on genealogical practices of the Self in the public realm, as new possibilities for genealogical research are becoming available for individuals. These new tools will allow them to reconstruct personal genealogies and identities in various manners and may complement or even eclipse the more traditional sources of identify-formation such as genealogical archives for pedigree or ancestor research. Increasingly, moreover, novel tools will be made available by commercial companies, triggering the curiosities or uncertainties of individuals concerning their ethnic origins and identities by providing sources of bioinformation pertinent to genealogical identity. The question than is, to what extent such emerging practices should be regarded as instances of empowerment and agency or rather as symptomatic evidence of new practices of segregation and classification? Are the individuals involved the subjects of new practices of Self-formation, or rather the objects of marketing strategies, that is: mere consumers of novel genomics products? Will these products incite experiences of belonging, or rather practices of exclusion? Last but not least, are current bioethical repertoires able to address such issues? In other words, although collectively, individually as well as historically new forms of bioinformation are affecting our views about ourselves, it is far from clear how these newly emerging options and perspectives are to be assessed.

A bioethical assessment must build, however, on an anthropological one. Anthropological issues must be addressed first in order to prepare the terrain, as it were, for bioethical inquiries. What exactly is the impact of these novel possibilities for identity formation on our selfimage? How, for instance, is genomics-based bioinformation affecting our views on the relationship between human beings and other species? Questions of this type must be clarified before we can take the ethical approach. And they traditionally belong to the special sub-discipline within philosophy called "philosophical anthropology", a research field that became specialised in assessing and "absorbing" the insights and findings of natural and human sciences. Implicitly or explicitly, our philosophical anthropology will affect the ways in which bioethical issues (notably issues concerning the application of genomics-based biotechnologies to human beings) will be articulated and addressed. Therefore, it can be regarded as the missing link, the intermediary zone between the philosophy of biology (which tends to study human beings from a biological or species perspective) and bioethics (which tends to see human beings as autonomous and responsible subjects, different from animals).

Traditionally, philosophical anthropology was dominated by an anthropocentric and humanistic conception of what it means to be human. In the face of novel forms of bioinformation as described above, this humanistic vision 
of ourselves is under siege. In response to the emergence of genomics and bioinformation, a debate is developing between a "humanistic" and a "post-humanistic" perspective on the past, present and future of mankind. The way we position ourselves in this debate will profoundly affect how we will assess a number of recent biomedical developments (such as cloning, genetic modification, or tissue engineering). In other words, our basic self-image, our "philosophical anthropology" will determine to a significant extent our involvement in bioethical deliberations. Implicitly or explicitly, a philosophical anthropology is always informing our bioethical views. New forms of bioinformation challenge us to take position and to opt, either for a humanistic or for a post-humanistic view. In the following sections, both positions will be represented by recent publications of prominent spokespersons, one for each view, namely Francis Fukuyama (representing "humanism") and Peter Sloterdijk (representing "posthumanism"). In this respect, this paper constitutes a counterpart or complement to a similar debate staged by Andrew Edgar in his contribution to this thematic issue between Habermas (representing humanism) and his transhumanist antagonists (Edgar 2009).

\section{The humanistic response: Francis Fukuyama on human dignity}

In his book Our posthuman future Francis Fukuyama (2002) has argued that, due to recent scientific developments, our uniqueness-the ontological discontinuity between human beings and other species-has to be redefined. He builds his argument on the observation that we find ourselves in the midst of a monumental period of advance in the life sciences and that this revolution challenges us to rethink the way we envision ourselves. Science and technology, rather than political ideologies, have become the powers that are now shaping human history. Due to Darwinism we already came to see ourselves as the temporary product of an evolutionary process that had been going on for millions of years and will continue well into the future (p. 6). The implication was that there appeared to be no fixed human characteristics. And this already posed a problem for a humanistic understanding of our "humanness". Characteristics that we tend to regard as "essentially" human and as exemplifying human dignity are in reality the accidental by-products of our evolutionary history. Apparently, there seems to be no such thing as human nature. Rather, human nature seems to be fundamentally changeable. And if we insist on identifying one specific feature as "typically human", it will probably be our general capability to choose what we want to be, to modify ourselves in accordance with our desires. So, "why don't we simply accept our destiny as creatures who modify themselves?" (p. 6).

Fukuyama, however, is not willing to accept this apparently inevitable conclusion. Rather he argues that human nature does exist and that it provides a stable continuity to our experience of ourselves as a species (p. 7). According to Fukuyama, our essential characteristics, our "human nature" has remained fairly stable throughout history (p. 13). Although cultural evolution and technological progress have led many modern thinkers to believe that human beings are almost infinitely plastic (p. 13), our essential humanness has remained unaffected since time immemorial.

Building on the writings of Kass (1993) and others, Fukuyama argues that technology has always played a somewhat ambivalent role in human history. On the one hand, technology is the basis of our freedom. At the same time, however, technology very often entails the threat of dehumanisation and enslavement. Many technological advances of the past actually reduced human freedom. The development of Neolithic agriculture, for example, led to the emergence of large hierarchical societies and made slavery more feasible than it had been in hunter-gatherer times (p. 15). This dual nature of technology notably applies to the genomics-based biotechnologies of the present. According to Fukuyama, the HGP has opened up new possibilities to manipulate human nature. Thus, genomics directly or indirectly poses a threat to human dignity. In the future, more precise knowledge of molecular and neural pathways may further our understanding of the genetic basis of behaviour. Indeed, "the sheer accumulation of knowledge about genes and behaviour" (p. 31) may put changing human nature-genetic self-modification in the context of human enhancement - on the agenda.

In Fukuyama's book, this discussion is developed more or less along the three lines we distinguished above. The HGP makes it possible to redefine ourselves in terms of our genome, both individually and collectively. This redefinition may fuel the desire to "improve" ourselves. As soon as we have assessed our strengths and weaknesses, either collectively or individually, biotechnology may subsequently provide us with the tools to boost our strengths and diminish our deficiencies. We may want to enhance the human condition through genetic self-amelioration. In contrast to the eugenic movement of the past, moreover, such a "new" eugenics may well develop in a liberal, bottom-up fashion, and enhancement may be pursued by individuals themselves. We are already using drugs such as Prozac that are part of the "neurotransmitter revolution" in order to modify our basic mood or state of mind, for instance by increasing the level of serotonin in our brain (Svenaeus 2007, 2009). The next step will come when pharmaceutical companies will make it possible to tailor 
this type of drug administration to genetic profiles of individual consumers. And finally, instead of taking drugs, it may become possible to enhance our state of mind in more direct and lasting ways, namely by modifying the genetic networks that are involved in neurotransmitter biochemistry. Thus, in such a techno-cultural environment, Big Brother will no longer be necessary to put us on the route towards a genomics-based Brave New World.

Yet, notwithstanding the opportunities and benefits this may offer to individuals suffering from depression, deficient impulse control, susceptibility to alcoholism and similar behavioural problems, a threat may emerge on the collective level, namely the threat that biotechnology "will cause us in some way to lose our humanity - that is, some essential quality that has always underpinned our sense of who we are and where we are going, despite all of the evident changes that have taken place in the human condition through the course of history" (p. 101). Worse yet, we might make this change "without recognizing we had lost something of great value" (idem). We might thus emerge "on the other side of the great divide between human and posthuman history and not even see that the watershed had been breached because we lost sight of what that essence was" (ibidem).

At the same time, however, genomics comes to our rescue as it were, because it allows us, much more precisely than ever before, to define what it is that makes us human. It may help us to outline the typical genetic "essence" of the human species, by elucidating the genetic basis of a number of specific cognitive features (p. 140). According to Fukuyama, genomics will reveal the existence of some essential human quality that is worth to be respected-and he calls it "Factor X" (p. 149), the human essence. This Factor $\mathrm{X}$ refers to the species-typical human characteristics that emerged $\sim 100,000$ years ago (p. 152), as the result of an "ontological leap" that occurred somewhere in the evolution process, an event that in the near future will be further elucidated by genomics research no doubt. According to Fukuyama, Factor $\mathrm{X}$ is a genetic endowment that distinguishes a human being in essence from other types of creatures (p. 171). It outlines the key qualities that contribute to human dignity and that we should want to protect from any future advances in biotechnology (p. 172). It constitutes the genetic constellation we should want to protect against attempts at self-modification (p. 172).

Finally, Fukuyama argues, genomics allows us to put this debate in a historical perspective. Human nature is the result of a long history that is reflected in our genomes. Somehow, we evolved into animals capable of self-modification. History has brought about huge changes in human perceptions and behaviours, to such an extent that a member of a hunter-gatherer society and an inhabitant of the contemporary information society may seem in many respects to belong to different species. Evolving human institutions and cultural arrangements have produced different human moral attitudes over time. Although the coming into being of mankind remains an essentially "mysterious process" (p. 176), evolutionary genomics may gradually elucidate this terra incognita. Yet, this new knowledge will also provide us with an unprecedented sense of power. The inevitable next step will be that we want to "breed something beyond man", that we may feel incited to by-pass the natural limits constraining the process of self-modification to what has hitherto been possible (p. 128). But Fukuyama does not want us to move in that direction, as it would entail a denial of the concept of human dignity, i.e. the idea that there is something unique about the human race that deserves to be protected. Therefore, the challenge for the future resides in the political control of biotechnology. The Factor X, or human nature genomically redefined - that which gives us a moral sense and provides us with the social skills to live in society, that which has been a constant ever since there have been human beings (p. 102)—should be safeguarded by establishing a robust and global regulatory framework.

\section{The post-humanistic response: Peter Sloterdijk on anthropotechnologies}

A prominent protagonist of the "post-humanistic" response is Peter Sloterdijk. Initially, both Fukuyama and Sloterdijk appear to move in similar directions, as Fukuyama's book opens with a quotation from Heidegger that also provides a starting point for Sloterdijk's line of thought-and that therefore deserves to be quoted in full, namely: "The threat to man does not come in the first instance from the potentially lethal machines and apparatus of technology. The actual threat ... threatens man with the possibility that it could be denied to him to enter into a more original revealing and hence to experience the call of a more primal truth". Yet, in Sloterdijk's case, this passage opens up a completely different, namely "post-humanistic" way of addressing the issue.

According to Heidegger, to whose work Sloterdijk devoted an important volume of essays $(2001),{ }^{7}$ we cannot understand ourselves as long as we regard mankind as a biological species. We are not an "animal rationale", $\mathrm{He}$ idegger argues, and the humanness of human beings cannot be grasped in biological terms. What characterises human existence is our remarkable openness towards the world.

\footnotetext{
$\overline{7}$ His famous, or infamous, lecture "Regeln für den Menschenpark: Ein Antwortschreiben zu Heideggers Brief über den Humanismus", by becoming embedded in this volume, is thereby placed in its proper theoretical context.
} 
We do not perceive the world merely in terms of food or opportunities for displaying species-characteristic behaviours. Rather, we tend to engage in an ethical, esthetical, epistemological and political manner ${ }^{8}$ with the world around us. We build a world. Or, as Heidegger phrases it: while animals are fully embedded in their natural environments, we stand out towards the world, we are dwelling in a "clearing" ("Lichtung"). But where does this openness, this clearing come from, how has it emerged? According to Heidegger, it is a gift from Being, a "Geschick des Seins" as he time and again phrases it. For Sloterdijk, this answer is no longer sufficient. In recent years, both the life sciences and the human sciences have evolved in such a way that it should now be possible to analyse more explicitly the genesis or genealogy of this "openness", this "clearing" that characterises human existence.

Technology has played a crucial role in the process of "anthropogenesis", the coming into being of mankind. Yet, while a "humanistic" anthropology will opt for a more or less instrumental view of technology, seeing human beings as producers and users of techniques and tools, Sloterdijk rather sees human beings as products of technological developments, as the outcome of a techno-cultural history. Since time immemorial, human beings and technology have been evolving interactively as it were. They are involved in a complicated process of co-evolution. This means that technology cannot be seen merely as an "instrument" for achieving certain goals. Rather, technology belongs to the core essence of what we are. Various techniques gave rise to practices such as reading, writing, calculating, and the establishment of legal and administrative networks that have shaped our emotions and cognitive functions. Our intelligence should not only be seen as a function of our neurological networks, but also as a function of the technocultural environments that we created and that actually facilitate-and to a certain extent even produce-intelligent types of behaviour. For example, our ability to calculate was considerably boosted by the introduction of Arabic numerals. Similar to the way thinking in general is intimately connected with language use, so specific forms of communication and transmission of information have brought forward particular forms of thinking.

Moreover, through technology, mankind has, since time immemorial, produced protective environments, life-worlds or "spheres" (Sloterdijk 1998, 1999, 2004). The prehistoric cave, where ancestors engaged in group dynamics, gathered around a domestic (domesticated) fire, was a first spheric, protective environment, an artificial uterus where human beings began to modify themselves and where, gradually, social, communicative and artistic skills became

\footnotetext{
${ }^{8}$ Politics may be here defined as: establishing laws based on principles and rights rather than power and status.
}

increasingly important in comparison to purely physical characteristics. Humans need these spheric, uterus-like extensions because we are born into this world prematurely, biologically speaking much too soon. These protective spheres, that have gradually evolved into increasingly complex constellations, allow us to dramatically extend the developmental stages of life. According to Sloterdijk, the ancient rural village was another "spheric" domestication scene, and the metropolises of the present can likewise be seen as techno-spheric constellation that protects us from the challenges of all-too-natural environments. Natural challenges are more or less replaced by technology-driven ones. These new challenges can be quite demanding, of course, but not in a purely physical sense. Rather they force us, but at the same time as enable us, to significantly enhance our cognitive and communicative talents.

In this context one specific concept is of crucial importance for Sloterdijk (2001) namely "antropotechnologies". These can be defined as technologies for hominisation, or civilisation of the human subject. According to Sloterdijk, human history can be described in terms of a series of anthropotechnologies that we developed in order to shape, transform and civilise mankind, both collectively and individually. A very important anthropotechnology has been "alphabetisation", the effort to teach individuals to read and write, to civilise them by exposing them to forms of transgenerational communication that were made possible by epistolary techniques for writing and reproducing texts. Initially, only the cultural elite had access to these new symbolic environments, but gradually, the alphabetisation process spread, like a cultural epidemic, until eventually even the lower strata of society were affected. Until recently, we relied primarily on "soft" anthropotechnologies such as training and education. In the near future, Sloterdijk argues, new generations of "hard" anthropotechnologies are likely to become available. Notably genomics-based biotechnologies will increasingly allow us to improve ourselves in more direct ways than has been possible in the past. We have always been improving ourselves, modifying ourselves, working on ourselves. There is no reason to expect that we will suddenly stop doing so, either now or in the future. Still, given the frightening and unprecedented powers these new biotechnologies are expected to set loose, a completely new form of ethics will have to be developed in order to allow us to govern and domesticate them.

As in the case of Fukuyama, Sloterdijk develops his views along the three lines distinguished in the beginning of the article. First of all, there is the historical or genealogical line of thinking. The life sciences, notably genomics, are shedding new light on the process of hominisation, the emergence of the clearing, this remarkable openness towards the world that is so essentially human. Our genomes contain the archives of this development and 
genomics research may be seen as complementing and deepening the knowledge coming from more traditional sources. Our genomes contain the footprints of this development, but in a rather specific way. We cannot meaningfully say that we are our genome, or that our genome is a kind of blueprint or mirror in which we can readily see and recognize ourselves. Rather, what we are is the outcome of an intricate co-evolution between our genomes and our technologies, between our genetic evolution on the one hand and the evolution of our technospheric environments on the other. Until now, we have studied this co-evolution primarily by focussing on the tool and techniques in which it became materialised (pottery, tools made from bones, stones, or iron up to paintings, ornaments and other artistic remainders). Now, the insights coming from these traditional sources are complemented by genomics evidence. It is by studying the interaction between genomic evolution and technocultural evolution that a comprehensive picture of human beings, journeying through history, becomes visible.

Besides this genealogical dimension, the post-humanistic position represented by Sloterdijk is interested in the individual and collective dimensions as well. Human beings are motivated by a will to improve themselves, a drive towards self-amelioration, either individually or collectively. Our life narratives and individual autobiographies are about learning from experience, about the acquisition of novel skills on order to face new challenges emerging in the context of rapidly transforming techno-cultural environments. This process will continue in the future. Why should we be satisfied with the ways in which we have developed so far? According to Sloterdijk, our practices of the Self, our "selflabour" as it were, is now entering a new phase. We will use our genomics insights to proceed with this process of selfamelioration, along two lines. First of all by using genomics information for self-management. We will increasingly tailor our life styles and training programmes to bioinformation concerning the strengths and weaknesses of our genome. But eventually, more and more opportunities will emerge that allow us to influence our genomes more directly. And the pace of techno-cultural development is such that in the future "soft" anthropotechniques may no longer suffice to adapt ourselves to the challenges of future environments in a sufficiently adequate way.

The basic flaw of humanism, as Sloterdijk sees it, is to define biotechnology as a threat coming from outside as it were. Rather, technology must be seen as part of our essence, as part of our way of being-in-the-world. We are not a purely natural entity that can be defined in terms of its genes. In the long-winded process of "hominisation" a great variety of technologies have played an active role. We are both the producers and the products of our "anthropogenesis". We are more or less man-made, the outcome of a long anthropogenic history. And there is no convincing reason why humanity as it has evolved so far should all of a sudden be "frozen", as it were, into its current state, why we should abandon our plasticity. In short, whereas the humanistic tradition sees it as our moral obligation to safeguard the integrity of the human subject vis-à-vis invasive technologies, Sloterdijk rather argues that we should be aware of the extent to which humanity and personhood are actually the products of techno-scientific developments. This does not mean that anything goes. On the contrary, Sloterdijk refers to the new anthropotechnologies of the future as "das Ungeheure", the immensely frightening. Yet, as long as we cling to humanistic strategies of immunisation, we will not be able to adequately prepare ourselves for the future that is rapidly coming towards us.

As Sloterdijk (2001) points out, through genomics and brain research, techno-scientific developments are now entering the very "citadel" of human personhood. This not only affects our understanding of ourselves, but also our repertoire of possibilities for modifying our vicissitudes as human beings, notably in terms of counteracting neurophysical decline. ${ }^{9}$ The question will be who is to assess and determine the societal impact of these developments? Who is to determine what possible pathways are to be developed and what pathways are to be avoided? Will these decisions be made on an individual, or rather on a collective levelin the context of "practices of the Self" or in the context of "biopower", to use a Foucauldian formulation? Unlike "transhumanists", who vigorously advocate upcoming possibilities of improving ourselves, the post-humanist Sloterdijk rather tends to steer a middle course by indicating, on the one hand, that we will be open in principle to genomics-based modifications, sometime in the near or distant future, while on the other hand urging us not to exaggerate our expectations in this direction. ${ }^{10} \mathrm{We}$ are neither to close our eyes to what is happening, nor are we to put ourselves at the mercy of overoptimistic visions of emerging prospects for human "enhancement". ${ }^{11}$

\section{An emerging anthropology in outline}

In the course of history, human beings have dramatically transformed themselves, either directly (through training

\footnotetext{
9 "Im Fortgang der technologischen Evolution wird die Zitadelle der Subjektivität, das denkende und erlebende Ich, angetastet“ (p. 220).

10 "Der Mens [ist] ein Produkt ... ein für weitere Ausarbeitung offenes" (p. 167).

11 "Dies hätte zur Voraussetzung, dass die Forschergemeinschaft wie die Gesellschaften Einsicht nähmen in die evolutionären und kulturellen Bedingungen des Ausnahme-Wesens, dessen genetische Information sie in einzelnen Fällen zu manipulieren vorhaben. Insbesondere kommt es darauf an, sich von überspannten Optimierungsvorstellungen fern zu halten" (p. 203).
} 
and civilisation) or indirectly (through developing the technocultural environments that have shaped us), and we will continue to do so in the future. Hegel once noted that our moral conscience is neither given nor fixed. Rather, it constitutes an evolving dimension of what we are. The Greek, as he phrased it, did not yet have a conscience as we know it, ${ }^{12}$ and even the "demonic" conscience of Socrates was quite unlike ours. A century later, Freud in his turn discovered that, besides our conscience and our consciousness, even our "unconscious" has a history (Lacan 1978). Yet, from a historical perspective, all these changes in personality structure, faithfully recorded in countless written documents, are fairly recent. As "excessive" information is now quickly accumulating concerning changes that took place $\sim 10,000$ or even $\sim 100,000$ years ago, our temporal horizon is broadening. The true scope of our journey towards humanness becomes visible. And in view of our remarkable plasticity, it would be artificial indeed to define human nature in an essentialist way. We are changing entities, constantly evolving, and to define human nature "biologistically", that is: in biological and even genetic terms, as Fukuyama urges us to do, does not seem to do justice to our openness to the world, our openness to change.

Both Fukuyama and Sloterdijk agree that we are currently finding ourselves on the threshold of a new era in which the technosciences will become the major propelling force, but from that point onwards their prognoses differ. Although they represent contrary positions, they actually do so in fairly moderate and nuanced ways. Fukuyama is moderate in the sense that he is explicitly aware of our openness to historical change, as we have seen. And Sloterdijk is moderate in the sense that he does not share the euphoric assessments of the promises of human enhancement articulated by so-called "transhumanists" such as Nick Bostrom. ${ }^{13}$ Interestingly, however, in at least one respect Fukuyama's views are more congenial with those of these fairly "radical" trans-humanists than with those of Sloterdijk. Both Fukuyama and Bostrom fall victim to the pitfalls of genetic determinism. "Transhumanism", the conscious will to go beyond humanity as it has evolved so far, is depicted by Fukuyama as a major threat to human culture. And it is in the face of this threat that he proposes to determine the unique genetic human constitution (our "Factor X") as something to be preserved, a genetic endowment that allows us to become human, distinguishing us "in essence from other types of creatures" (p. 171). Obviously, however, both Fukuyama and his trans-humanistic antagonists start from the idea that

\footnotetext{
12 „So sind sie - so leben sie/Griechen hatten kein Gewissen/ ... Können keine Rechenschaft geben, kein Gewissen “ (Hegel 1970, zu § 147).

13 http://www.nickbostrom.com/.
}

we apparently are our genes, and that we can modify ourselves (for better or for worse) or maintain ourselves by adding, deleting or preserving genes. This idea of genetic "determinism" is blatantly at odds with the complexities of causal trajectories from genes to traits that are actually being explored and revealed by genomics research (Zwart 2007a, b). Life is really far too complex for such scenarios to be credible. The historical vicissitudes of our conscience, our consciousness and the unconscious emerge against the backdrop of an ongoing dialogue between genomes and technologies. Thus, while humanism and transhumanism mirror one another, as they actually build in similar flaws, Sloterdijk's view emerges as the more congenial starting point for future debate.

There will always be a tension between our "Palaeolithic" genome and our contemporary techno-cultural environments. Time and again, new generations of "barbarians" are born into this world whose DNA carries a genome sequence that has evolved under Palaeolithic conditions and who therefore have to become civilised one way or the other in order to flourish in the context of our life-worlds. Biological (Darwinian) evolution is much too slow to keep up with the accelerating pace of techno-cultural change. Therefore, the distance between our genome and our advancing technocultural environments is bound to increase. Society can basically be seen as a kind of ongoing "dialogue" between the two. And one could argue that behavioural genomics basically focuses on those genetic factors that, in view of their "Palaeolithic" origins, fail to meet the demands of modern societies. Yet, it would be naïve to think that this can be achieved by safeguarding, adding or deleting single genes. Rather, we will have to focus on the complex interplays between networks of genetic and environmental factors explored by genomics research.

As genomics is taking us beyond the paradigm of genetic determinism, self-amelioration by adding or deleting genes becomes increasingly implausible. What is much more likely is that genomics information will increasingly influence our practices of identity-formation, will increasingly be built into our "presentations of Self in everyday life", as Goffmann (1959) phrased it, will be absorbed into our selfimages, in order to tailor our practices of Self to our personalised genome sequences. We will keep working on ourselves, no doubt, not by modifying our genomes, but rather by fine-tuning our "soft" anthropotechnologies on the basis of novel forms of bioinformation. To articulate this in phenomenological terms: what we are experiencing is a bioinformatisation of the life-world. Genomics-based technologies have begun to pervade our daily lives, our autobiographies and narratives, as well as our anthropologies, rather than our genomes as such.

Eventually, the implications of these developments must be addressed in bioethical terms: in terms of agency. This 
requires bioethical principles that operate on the level of the Self, addressing questions such as: Who can be regarded as the author of these novel genomics-based identities that are envisioned? Will these new technologies invite individuals to constitute themselves as subjects, or will new identities rather be produced by emerging discursive practices and strategies of classification and demarcation? Rather than trying to distinguish these options as distinct scenarios, we should acknowledge that they belong together as complementary dimensions or axes of one and the same development. We are authors of new types of biographies, but also temporary outcomes or products of new discursive pathways. A comprehensive view should combine an epistemology of the new knowledge forms that are emerging with analyses, both of the genomics-based governance regimes they generate and of the practices of identity-formation they enable.

Open Access This article is distributed under the terms of the Creative Commons Attribution Noncommercial License which permits any noncommercial use, distribution, and reproduction in any medium, provided the original author(s) and source are credited.

\section{References}

Asherson, P. 2005. Behavioural genomics: an integrated approach. Psychiatry 4: 1-5.

Cavalli-Sforza, L.L., and F. Cavalli-Sforza. 1995. The great human diasporas. The history and diversity of evolution. New York: Basic Books.

Collins, F., E. Green, A. Guttmacher, and M. Guyer. 2003. A vision for the future of genomics research. A blueprint for the genomics era. Nature 422: 835-847.

Copernicus, N. 1978/1992. Complete works. Baltimore and London: The Johns Hopkins University Press.

Crichton, M. 2006. Next. New York: Harper Collins.

Edgar, A. 2009. The hermeneutic challenge of genetic engineering: Habermas and the transhumanists. Medicine, Health Care and Philosophy. doi:10.1007/s11019-009-9188-9.

Freud, S. 1917/1947. Eine Schwierigkeit der Psychoanalyse. Gesammelte Werke XII, 3-12. London: Imago.

Fukuyama, F. 2002. Our posthuman future. Consequences of the biotechnology revolution. New York: Farrar, Straus and Giroux.

Gaskell, G., and M.W. Bauer (eds.). 2006. Genomics \& society. Legal, ethical \& social dimensions. London: Earthscan.

Goffmann, E. 1959. The presentation of Self in everyday life. Garden City, NY: Doubleday.

Hegel, G.W.F. 1821/1970. Grundlinien der Philosophie des Rechts [Philosophy of Right]. Werke in zwanzig Bände 7. Frankfurt: Suhrkamp.
IHGSC. 2004. Finishing the euchromatic sequence of the human genome. Nature 431: 931-945.

International Human Genome Sequencing Consortium (IHGSC). 2001. Initial sequencing and analysis of the human genome. Nature 405: 860-921.

Jones, M. 2001. The molecule hunt. Archaeology and the search for ancient DNA. New York: Arcade Publishing.

Kass, L. 1993. Introduction: the problem of technologies. In Technology in the Western political tradition, ed. A.M. Melzer et al. Ithaca: Cornell UP.

Lacan, J. 1978. Le séminaire de Jacques Lacan. Livre II: Le moi dans la théorie de Freud et dans la technique de la psychanalyse (1954-1955). Paris: Éditions du Seuil.

Larson, G., et al. 2007. Ancient DNA, pig domestication and the spread of the Neolithic into Europe. Proceedings of the National Academy of Sciences (PNAS) 104: 15276-15281, London etc.: Penguin.

M'charec, A. 2005. The human genome diversity project: An ethnography of scientific practice. Cambridge: Cambridge University Press.

Nash, C. 2005. Geographies of relatedness. Transactions of the Institute of British Geographers 30: 449-462.

Normile, D., and E. Pennisi. 2002. Rice: Boiled down to bare essentials. Science 296: 32-36.

Sloterdijk, P. 1998. Sphären I: Blasen. Frankfurt am Main: Suhrkamp.

Sloterdijk, P. 1999. Sphären II: Globen. Frankfurt am Main: Suhrkamp.

Sloterdijk, P. 2001. Nicht gerettet. Versuche nach Heidegger. Frankfurt: Suhrkamp.

Sloterdijk, P. 2004. Sphären III: Schäume. Frankfurt am Main: Suhrkamp.

Stevenson, R.L. 1886/1981. Dr. Jekyll and Mr. Hyde. New York: Bantam Books.

Stone, L., and P. Lurquin. 2005. A genetic and cultural odyssey. The life and work of L. Luca Cavalli-Sforza. New York: Columbia University Press.

Svenaeus, F. 2007. Do antidepressants affect the self? A phenomenological approach. Medicine, Health Care and Philosophy 10: 153-166.

Svenaeus, F. 2009. The ethics of self-change: becoming oneself by way of antidepressants or psychotherapy? Medicine, Health Care and Philosophy. doi:10.1007/s11019-009-9190-2.

Thacker, E. 2005. The global genome. Biotechnology, politics and culture. Cambridge: MIT Press.

Venter, J.C. 2007. A life decoded. My genome: My life. Viking Penguin: New York.

Zwart, H. 2007a. Genomics and self-knowledge. Implications for societal research and debate. New Genetics and Society 26 (2): 181-202.

Zwart, H. 2007b. Next [Book review]. Genomics, Society \& Policy 3 (1): 48-51. 